\title{
Evolution of pyrrhotite oxidation in aggregates for concrete
}

\author{
I. Oliveira, S.H.P. Cavalaro $\bowtie$, A. Aguado \\ Universidad Politécnica de Cataluña, BarcelonaTech, (Barcelona, Spain) \\ $\triangle$ sergio.pialarissi@upc.edu
}

\author{
Received 25 September 2013 \\ Accepted 7 November 2013 \\ Available on line 17 November 2014
}

\begin{abstract}
Rocks containing pyrrhotite bands are sometimes used to produce concrete. These rocks oxidize and produce long-term expansive reactions that damage concrete structures, leading to important economic and risk related repercussions. The present study analyses several aspects that affect the oxidation process of the aggregate such as the existence of preferential paths for the entrance of the oxidizing agent and the conversion process of the chemical elements involved in the reaction. For that, host rock samples containing pyrrhotite were investigated by scanning electron microscopy and energy dispersive spectroscopy. The results shows that the pyrrhotite appears in bands that create planes of weakness and present cracks that serve as preferential paths for the entrance of oxygen. Furthermore, a new representation is proposed for the oxidation process.
\end{abstract}

KEYWORDS: Iron sulfide; Oxidation; Aggregate; Internal sulfate attack; Dam

Citation / Citar como: Oliveira, I.; Cavalaro, S.H.P.; Aguado, A. (2014) Evolution of pyrrhotite oxidation in aggregates for concrete. Mater. Construcc. 64 [316], e038 http://dx.doi.org/10.3989/mc.2014.08413.

RESUMEN: Evolución de la oxidación de la pirrotina presente en áridos para hormigón. Rocas con bandas de pirrotina han sido usadas para producir áridos destinados a la fabricación de hormigones. Las mismas son susceptible a un fenómeno de oxidación que a largo plazo produce la degradación del material, llevando a importantes repercusiones económica y en cuanto a la seguridad. El presente estudio evalúa la influencia de diferentes aspectos que pueden afectar dicho proceso de oxidación del agregado, tales como la existencia de caminos preferentes para la entrada del agente oxidante y los elementos químicos involucrados en la reacción. Para ello, muestras de roca con pirrotina han sido analizadas mediante microscopía electrónica de barrido. Los resultados indican que la pirrotina aparece en bandas que dan lugar a planos de debilidad y fisuración. Esas fisuras actúan como caminos preferentes a la entrada del oxígeno. Asimismo, con base en los análisis realizados se ha propuesto una nueva representación para el proceso de oxidación.

PALABRAS CLAVE: Sulfuro de hierro; Oxidación; Árido; Ataque sulfático interno; Presa

Copyright: (C) 2014 CSIC. This is an open-access article distributed under the terms of the Creative Commons Attribution-Non Commercial (by-nc) Spain 3.0 License.

\section{INTRODUCTION}

Geological formations of endogenous and metamorphic host rocks with inclusions of pyrrhotite bands may be found in Nature. In some cases, these rocks have been used to produce aggregates that were then incorporated in the dosage of concrete. Elements cast with this material have shown severe cracking caused by an expansive phenomenon known as internal sulfate attack (ISA). In such phenomenon, the particles of pyrrhotite included in the aggregates oxidize, producing iron hydroxides and sulfates (1). The latter reacts with calcium and the aluminates from the cement paste to form expansive secondary ettringite.

Several examples of structures affected by the presence of this harmful material are found in the literature. Some of these studies remark the important economic, social and risk related repercussions of using the contaminated rocks in concrete (2-7). Figure 1 shows the case of the downstream face and the galleries of the Graus Dam (Spain), which shows severe cracking and movements due to the ISA. 
The rate and the overall repercussions of the ISA are clearly dependent of the interaction between the particle and the surrounding host rock that forms the aggregate. Factors such as the pyrrhotite concentration in the host rock and the oxygen access (oxidizing agent) may affect the oxidation process. Therefore, the characterization of this reaction in the host rock is a fundamental step towards understanding, modeling and properly treating the degradation observed in the concrete.

The objective of this paper is to analyze three aspects that may affect the oxidation process of pyrrhotite particles inside the aggregate: the shape and the integrity of the particle, the existence of preferential paths for the entrance of oxygen and the conversion process of the chemical elements involved in the reaction. For that, host rock contaminated with pyrrhotite particles were extracted from quarries and used to produce samples. The latter were investigated by scanning electron microscopy and energy dispersive spectroscopy (SEM/EDS).

The study shows that the pyrrhotite appears in bands that create planes of weakness in the rock. Cracks observed in these bands serve as preferential paths for the entrance of oxygen. Furthermore, a new representation is proposed for the pyrrhotite oxidation process. Both observations denote a significant contribution towards the development of more realistic models to predict the evolution of the ISA.

\section{BACKGROUND ON PYRRHOTITE OXIDATION}

The oxidation process of pyrrhotite may be caused either by the activity of microorganisms or by the direct chemical reaction with the compounds present in the atmosphere under favorable conditions. Even though the former is more frequent in Nature, the latter is the focus of the present study since it is the one usually observed in concrete structures subjected to ISA. In this case, the access of the oxygen $\left(\mathrm{O}_{2}\right)$ and of the moisture $\left(\mathrm{H}_{2} \mathrm{O}\right)$ are essential to initiate the reaction (9-13), as shown in eq. [1]. Notice that the original iron content in the pyrrhotite stoichiometry may range from 0.875 to $1.000(15,16)$. According to Schmidt et al. (14), this pyrrhotite reacts to form first iron oxide $\left(\mathrm{Fe}_{2} \mathrm{O}_{3}\right)$ and then iron hydroxides $\left(\mathrm{Fe}(\mathrm{OH}), \mathrm{Fe}(\mathrm{OH})_{3}\right)[1]$.

$$
\begin{aligned}
\mathrm{Fe}_{1-\mathrm{x}} \mathrm{S} & +\left(\frac{10-3 \mathrm{x}}{4}\right) \mathrm{O}_{2}+\left(\frac{4-3 \mathrm{x}}{2}\right) \\
& \times \mathrm{H}_{2} \mathrm{O} \rightarrow(1-\mathrm{x}) \mathrm{Fe}(\mathrm{OH})_{3}+\mathrm{SO}_{4}^{2-}+\mathrm{H}^{+} \mathrm{Eq} \cdot[1]
\end{aligned}
$$

The evaluation of the oxidation process is often performed through a scanning electron microscopy with microanalysis (SEM/EDS) since the EDS can quantify the chemical elements present in the samples analyzed. The atomic ratios obtained from this analysis serve to assess the compound present at a given point and time throughout the course of the reaction.

In order to facilitate the identification of the chemical compounds involved, a graphical representation of the pyrrhotite oxidation is commonly used. These graphs define a Cartesian system with axis $\mathrm{X}$ and $\mathrm{Y}$, each of them corresponding to a different atomic ratio between the contents of two chemical elements obtained from the microanalysis. For each analyzed portion of the sample, a pair of atomic ratios is obtained, making it is possible to define a point in the Cartesian system.

Depending on the point position with reference to the axis, the chemical compound in the analyzed zone is determined. This approach allows an easy comparison of the composition of different zones of the same sample and outlines the path and the stage of conversion of the chemical compounds during the reaction.

To represent the iron sulfides oxidation process, Schmidt et al. (14) used a graph relating the atomic ratio between sulfur and iron $(\mathrm{S} / \mathrm{Fe})$ in the $\mathrm{Y}$-axis with the atomic ratio between oxygen and iron $(\mathrm{O} / \mathrm{Fe})$
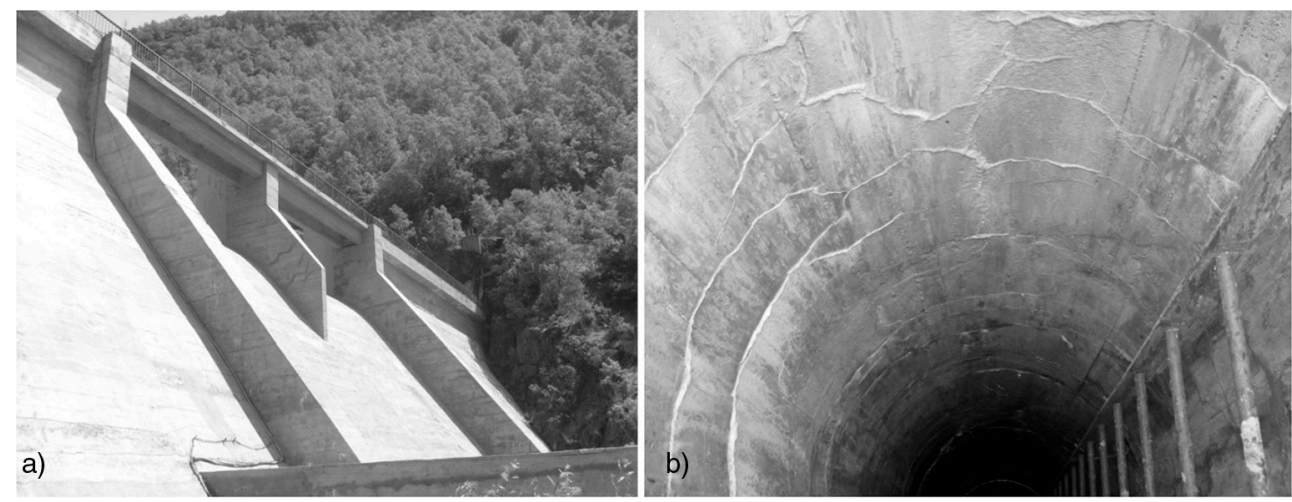

FIGURE 1. Detail of a) downstream face and b) crest crack at the Graus Dam (8). 
in the $\mathrm{X}$-axis. It seems clear that the plot from Figure 2a proposed by Schmidt et al. (14) reflects a simplified evolution of pyrite and pyrrhotite oxidation reaction which is also observed during the ISA. In this representation the author has used the results obtained in zones of the iron sulfide particles that are either clearly oxidized or not. As a result, there is a concentration of points either near the Y-axis (indicating the iron sulfide after the oxidation process) or near the $\mathrm{X}$-axis (showing the oxidation products). There are no dots indicating the conversion or the movement between the axes. Thus, a more detailed description of the iron sulfides oxidation conversion requires the analysis of a greater amount of points in the transition zone between the oxidized and the non-oxidized iron sulfide.

Mycroft et al. (17) and Pratt et al. (18) have proposed a slightly different oxidation process (Figure 2b). Based on a study of depth profiling with AES (Auger Electron Spectroscopy), they determined the chemical composition profile of the pyrrhotite surface. The authors noted that the deepest layer of the particle is composed of unreacted pyrrhotite; the second layer is a mixture of $\mathrm{Fe}_{2} \mathrm{~S}_{3}$ and $\mathrm{Fe}_{7} \mathrm{~S}_{8}$, while the next layer is pyrrhotite with a stoichiometry approaching of the pyrite (19). Finally, the external layer (pyrrhotite surface) is composed of iron oxyhydroxide resulting from the oxidation process.

To justify the profile Mycroft et al. (17) and Pratt et al. (18) considered that the pyrrhotite oxidation causes iron to diffuse from inside to outside the particle. This displacement of iron results in an enrichment of sulfur in the zone below and promotes the formation of disulphide bonds and the reorganization of the pyrrhotite structure towards marcasite $\left(\mathrm{FeS}_{2}\right)$ or a disordered pyrite structure (19-22).

\section{EXPERIMENTAL PROGRAM}

In order to obtain a clearer picture of the evolution and the factor affecting the pyrrhotite oxidation, an extensive set of rock samples were extracted from the quarry located in the right abutment of the Rumedo dam. This is a concrete dam built in Lladorre (Spain) by 1971 with a $91 \mathrm{~m}$ of length and $9 \mathrm{~m}$ of height severely affected by the ISA.

The rocks collected from the quarry were crushed and divided into 4 different grading ranges: 4 to $5 \mathrm{~mm}$ (A), 5 to $20 \mathrm{~mm}$ (B), 20 to $40 \mathrm{~mm}$ (C) and 40 to $50 \mathrm{~mm}$ (D). The physical properties testing showed that the porosity and the density of the host rock are $2.17 \%$ and $2.73 \mathrm{~g} / \mathrm{cm}^{3}$, respectively. The chemical analysis presented in the Table. 1 indicated high contents of iron compounds and a medium sulfur content $\left(\mathrm{SO}_{3}\right)$ equal to $1.42 \%$ that exceeds the maximum limits (minor then $1 \%$ of the total aggregate weight) established in many codes and guidelines. The variation in the contents of these elements does not seem to be influenced by the grading ranges.

The rock samples for scanning electron microscopy SEM (FIE QUANTA 200) were prepared from the host rock by cutting, grinding and polishing to give representative micro sections of the surface. The polishing was done in several steps by using diamond suspensions from 9 to $0.25 \mu \mathrm{m}$ (BUEHLER, Beta-vector). The polished samples were then coated with carbon to get an electrically conductive surface. The microstructure of the samples was examined by SEM using backscattered electron imaging (BSE) and energy dispersive X-ray spectroscopy (EDS). The chemical analysis using EDS was performed with a $\mathrm{Li} / \mathrm{Si}$ crystal detector and an accelerating voltage of $15 \mathrm{kV}$. The pyrrhotite oxidation was studied by EDS point analysis to determine the elements iron, sulfur and oxygen.

\section{RESULTS AND ANALYSIS}

\subsection{Pyrrhotite bands}

Pyrrhotite usually appears in the host rock concentrated in bands $(23,24)$. These bands form debility areas that create preferential zones for the crack appearance and grain size reduction (25). On visual a)

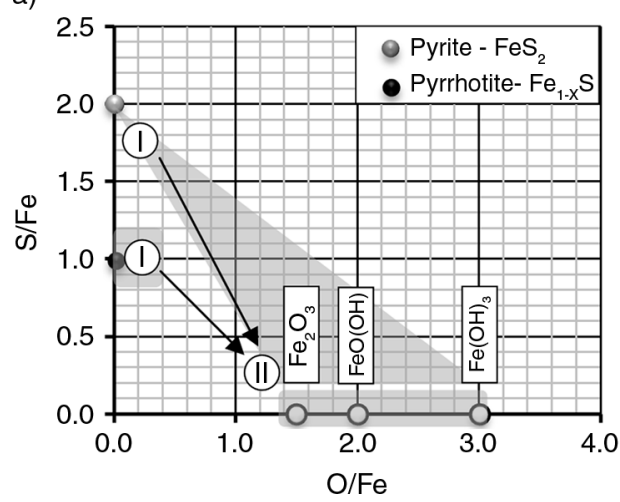

b)

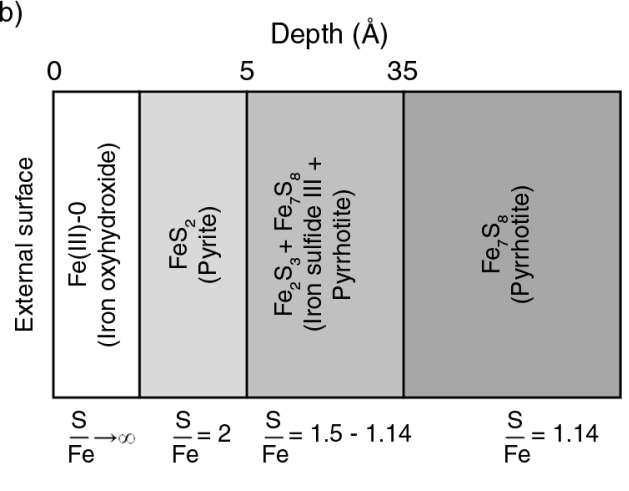

FIgURE 2. Pyrrhotite oxidation according to a) Schmidt et al. (14) and according to b) Mycroft et al. (17) and Pratt et al. (18). 
TABLE 1. Chemical composition of the rocks by XRF (values in \%)

\begin{tabular}{lcccccc}
\hline Óxidos & $\mathbf{A ~ ( 4 - 5 )}$ & $\mathbf{B ~ ( 5 - 2 0 )}$ & $\mathbf{C ~ ( 2 0 - 4 0 )}$ & $\mathbf{D ~ ( 4 0 - 5 0 )}$ & \multicolumn{1}{c}{$\overline{\mathbf{X}}$} & s.d. $(\boldsymbol{\sigma})$ \\
\hline \hline $\mathrm{Na}_{2} \mathrm{O}$ & 1.38 & 1.71 & 1.99 & 1.90 & 1.75 & 0.27 \\
$\mathrm{MgO}$ & 2.82 & 2.52 & 2.29 & 2.89 & 2.64 & 0.28 \\
$\mathrm{Al}_{2} \mathrm{O}_{3}$ & 18.20 & 16.79 & 17.30 & 19.88 & 18.05 & 1.36 \\
$\mathrm{SiO}_{2}$ & 50.62 & 58.70 & 59.33 & 56.51 & 56.29 & 3.97 \\
$\mathrm{P}_{2} \mathrm{O}_{5}$ & 0.14 & 0.10 & 0.14 & 0.10 & 0.12 & 0.02 \\
$\mathrm{SO}_{3}$ & 1.72 & 1.50 & 1.06 & 1.38 & 1.42 & 0.28 \\
$\mathrm{~K}_{2} \mathrm{O}$ & 3.43 & 3.01 & 2.92 & 4.21 & 3.40 & 0.59 \\
$\mathrm{CaO}$ & 3.87 & 0.73 & 0.70 & 0.03 & 1.34 & 1.72 \\
$\mathrm{TiO}_{2}$ & 0.88 & 0.80 & 0.64 & 1.06 & 0.85 & 0.17 \\
$\mathrm{Fe}_{2} \mathrm{O}_{3}$ & 11.02 & 8.34 & 8.08 & 8.47 & 8.98 & 1.37 \\
\hline
\end{tabular}

inspection performed in concrete samples extracted from Tavàscan and Graus dams, Aguado et al. (2) observed that aggregates with diameters between 30 and $70 \mathrm{~mm}$ showed pyrrhotite bands always smaller than $1 \mathrm{~mm}$ of thickness. The same authors have verified in others concretes that aggregates with diameter between 80 and $120 \mathrm{~mm}$ have pyrrhotite bands with thickness ranging from 0.5 to $1.0 \mathrm{~mm}$.

Figure $3 \mathrm{a}$ shows the rocks samples extracted from the quarry used in the construction of the Rumedo dam. As expected, during the crushing to produce the aggregates, it was observed that the fracture of the host rock usually occurred at the pyrrhotite band, which characterizes the debility zone. The intense dark brown color of the band is indicative of the goethite formation $\mathrm{FeO}(\mathrm{OH})$ - one of the products of the pyrrhotite oxidation. This suggests that, despite the protection provided by the surrounding rock, the band was in an advanced state of oxidation. Figure $3 b$ shows a BSE image of the analyzed rock, where a pyrrhotite band with a thickness of approximately $1.3 \mathrm{~mm}$ is clearly observed. A crack in the longitudinal direction parallel to the pyrrhotite band is also identified. In addition to forming a weakness layer in the rock, this crack marks a preferential path for the entry of oxygen, thus accelerating the pyrrhotite oxidation process. This explains the overall advanced stage of oxidation of the band shown in Figure $3 b$.

\subsection{Oxygen access in to the pyrrhotite}

To identify the presence of the oxygen in the pyrrhotite bands, a total of 16 samples of the host rock were analyzed. In each sample, two zones were identified. Zone I corresponds to the border between the pyrrhotite band and the crack (pyrrhotite surface), whereas zone II represent the central part of the pyrrhotite band. This work presents the microanalysis of the two most representative aggregate samples. The analysis of the complete set of samples may be found in Jones et al. (19).

Figure 4 shows the mapping of the pyrrhotite band in the aggregate with a magnitude increase of 2400X for the elements involved in the oxidation process (iron, sulfur and oxygen).

In Figure $4 b$ there are two clearly distinct areas: an oxidized one, which is dominated by the presence of iron (red), and one non-oxidized, which is dominated by the presence of sulfur (green) and
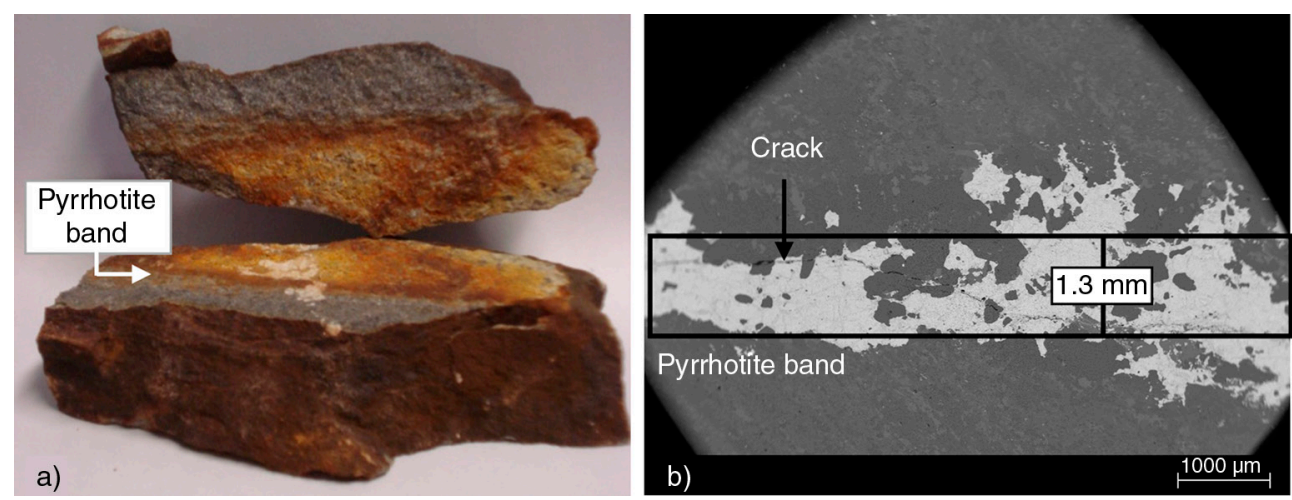

FIgURE 3. Host rock from Rumedo dam quarry: a) pyrrhotite band and b) BSE image. 

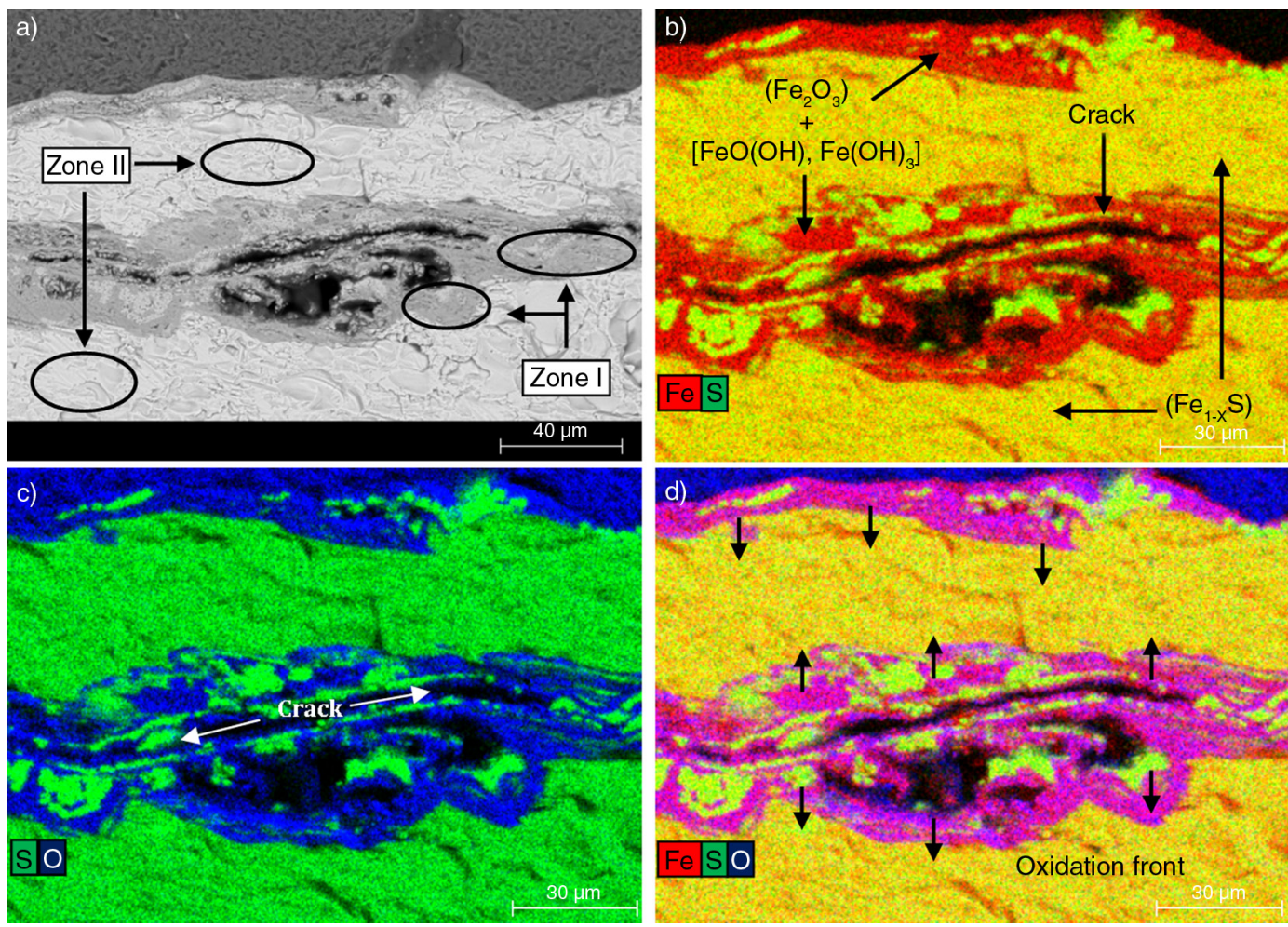

Figure 4. Mapping for the elements: a) BSE image, b) Fe-S, c) S-O and d) Fe-S -O.

iron (red). The combination of the colors represented by these two elements highlight the zones with pyrrhotite, marked in yellow. In fact, in Figure $4 \mathrm{c}$ it is observed that the cracks are completely filled by the oxygen, confirming the initial hypothesis that the crack is a preferential path for the oxygen entry.

The purple areas in Figure $4 \mathrm{~d}$ mark the oxidized zone and the direction of the oxidation front. It may be observed that the oxygen diffusion does not occur through the aggregate, since the pyrrhotite degradation was only noted in the border of the pyrrhotite and the crack. In Figure 4d the oxidation front is situated at the surface of the pyrrhotite particle. Such front moves to the center of the particle, leaving behind a complete oxidized pyrrhotite. As the oxidation process advances, the penetration and diffusion of the oxygen occurs through the iron hydroxide (oxidized pyrrhotite) towards the surface of the non-oxidized pyrrhotite.

Figure 5 shows the mapping of another sample of the pyrrhotite band present in the host rock. In this analysis, the same methodology presented in the Figure 4 was adopted.

A crack that cuts the pyrrhotite band is observed in Figure 5b. Moreover, Figure $5 \mathrm{c}$ shows that the areas with purple color located around the cracks have a high concentration of iron and oxygen. In Figure 5d, the blue color at the border of the crack indicates the presence of a high oxygen content, which marks the oxidation front. Both observations confirm that the cracks provide a preferred way for the oxygen entry, leading to the formation of iron oxides and hydroxides. The same patterns was observed in the great majority of samples analyzed in the present study.

\subsection{Analysis of pyrrhotite oxidation using SEM/EDS}

It is important to remark that the pyrite oxidation path of conversion is identical to the pyrrhotite, with the difference that the degradation process usually starts with an $\mathrm{S} / \mathrm{Fe}$ atomic ratio slightly higher. This happens since $\mathrm{S} / \mathrm{Fe}$ is equal to 2 for the pyrite and between 1 and 1.25 for the pyrrhotite.

Figure 6 shows the evolution of the oxidation of the two zones presented in Figure 4a. The points of zone I are dispersed due to the unstable concentrations of sulfur and oxygen (characteristic of the oxidation process). However, the points of zone II present no signs of oxidation, being concentrated in one region with an $\mathrm{S} / \mathrm{Fe}$ atomic ratio characteristic of the pyrrhotite.

Following the same procedure used in the analysis of the pyrrhotite previously presented, Figure 7 presents the evolution of the oxidation of the two zones marked in Figure 5a. The graphic shows that the points of zone II are concentrated in a region with low oxygen content and $\mathrm{S} / \mathrm{Fe}$ ratio between 

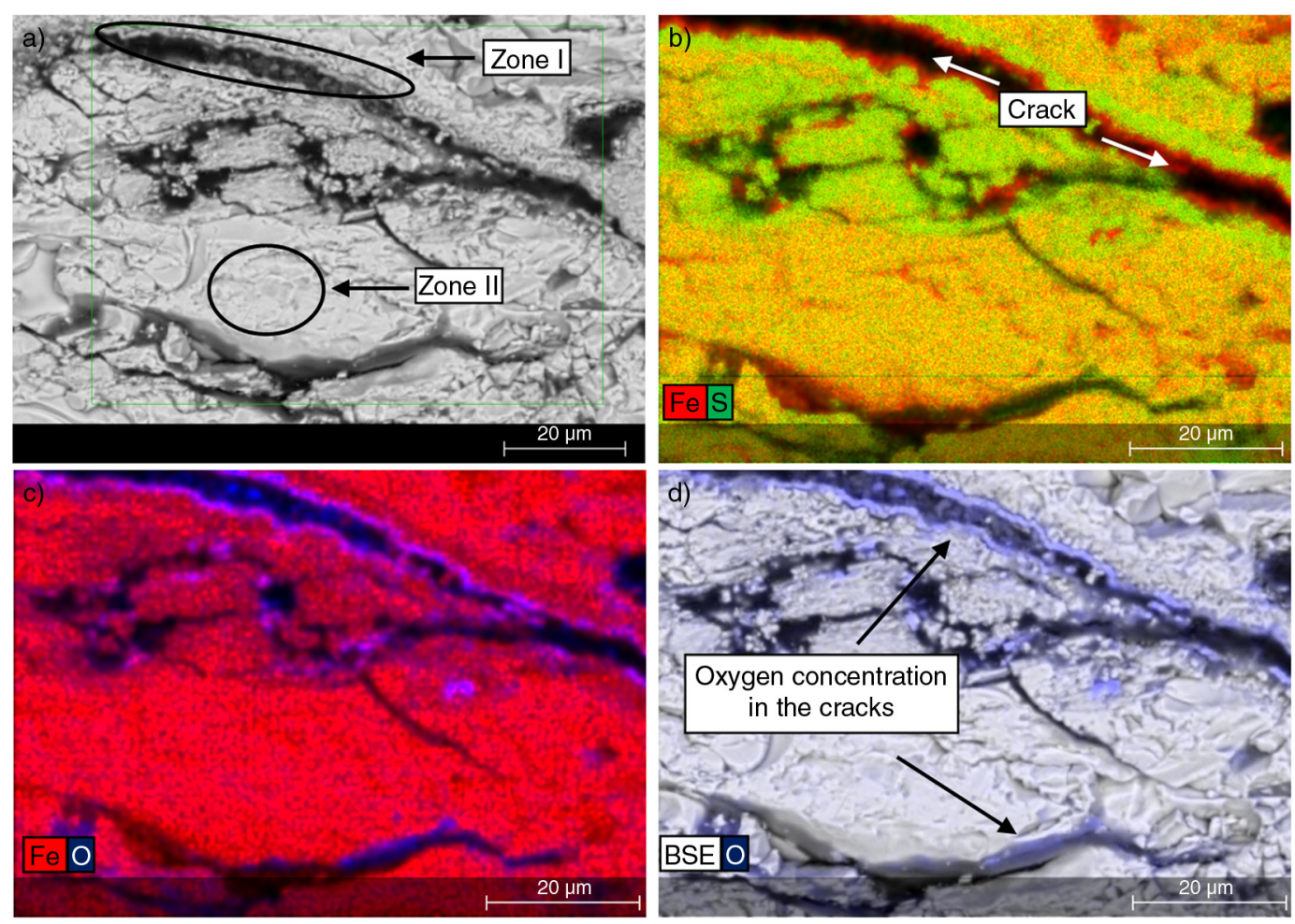

FIgure 5. Mapping for the elements: a) BSE image, b) Fe-S, c) Fe-O and d) O.

0.8 and 1 , reflecting the presence of non-oxidized pyrrhotite. Again, points in the zone I have higher oxygen content and lower sulfur content, indicating an advanced state of the pyrrhotite oxidation and the presence of a high content of iron oxides near the cracks.

In order to provide a general overview of the pyrrhotite degradation process, Figure 8 shows all the points discussed in the two samples presented in this study as well as the results of other 14 samples extracted from the same quarry. The figures include the data obtained for zones I and II. Notice that Figure 8a relates the atomic content of iron and

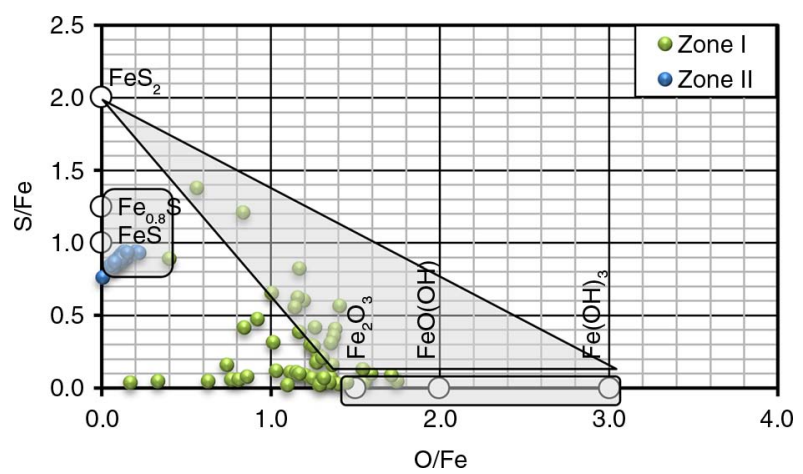

Figure 6. Oxidation process of the pyrrhotite presented in Figure 4 oxygen whereas Figure $8 \mathrm{~b}$ relates the atomic content of sulfur and oxygen for each point. The conversion point of the oxidation process for the iron and for the sulfur are clearly identified in both of them.

As may be seen, for low oxygen concentrations (non-oxidized points) iron contents show a decreasing linear tendency. On the contrary, the sulfur content is maintained with a steady tendency, despite its greater dispersion. This may reflect the diffusion of iron through the particle, which reduces the content of this element with respect to the sulfur content, characterizing the conversion of the pyrrhotite structure towards a disordered pyrite structure.

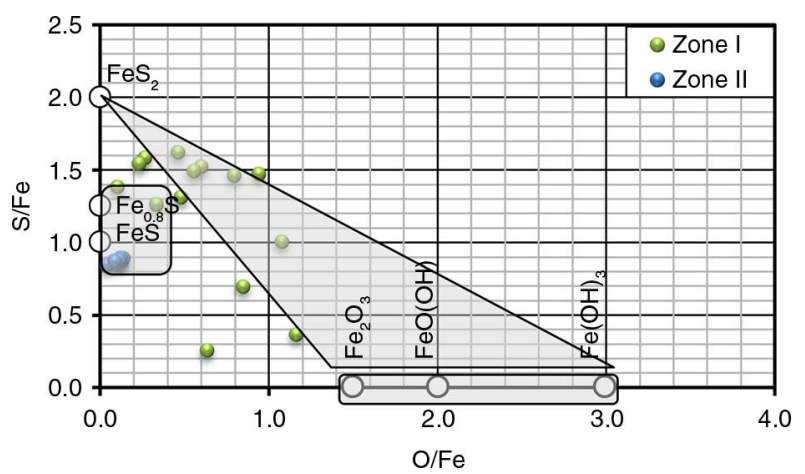

Figure 7. Oxidation process of the pyrrhotite presented in Figure 5. 
a)

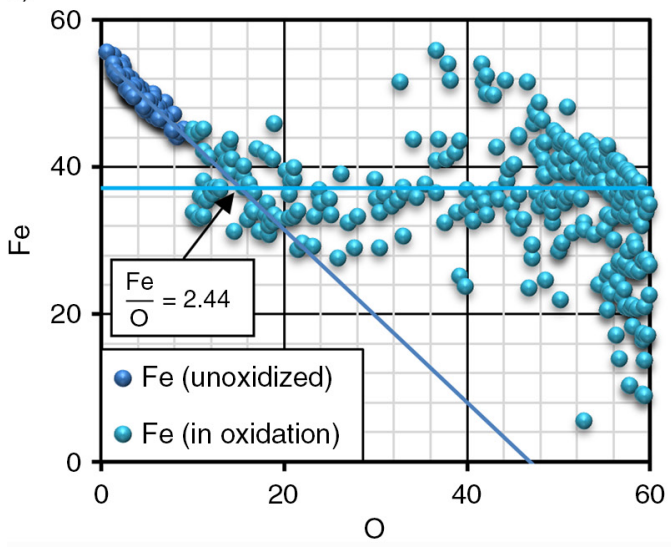

b)

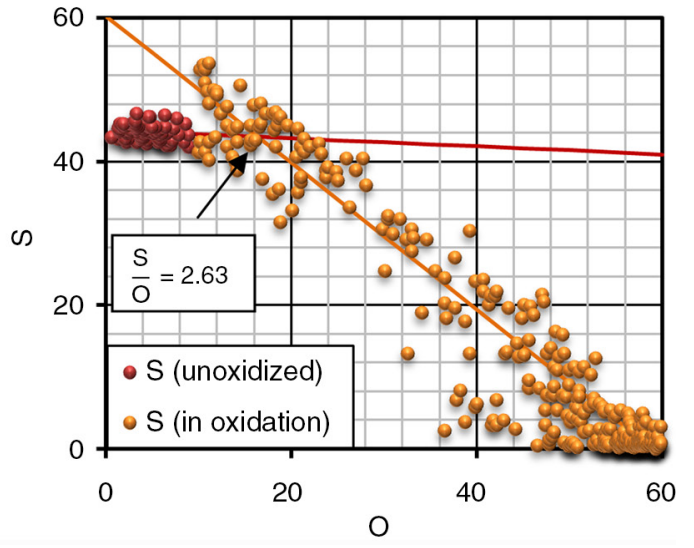

FIGURE 8. Conversion points of the pyrrhotite oxidation process.

Once the $\mathrm{Fe} / \mathrm{O}$ atomic ratio reaches 2.44 , a significant increase in oxygen content is observed while the iron content has a fairly constant tendency, even though with a high scatter (see Figure 8a). Such behavior indicates the formation of oxides and hydroxides of iron during the oxidation process. In the case of the sulfur (Figure $8 \mathrm{~b}$ ), once the $\mathrm{S} / \mathrm{O}$ atomic ratio equal 2.63, a considerable reduction of sulfur content takes place simultaneously with an increase in the oxygen content. This way, the points follow the downward tendency shown in orange in the graph in Figure 8b. This result suggests that the oxidation process, release sulfates that have some mobility and can leave the iron sulfide particles, causing the sudden decrease appreciated in the sulfur content. Notice that the characteristic ratios of 2.44 for the Fe/O and especially the limit of 2.63 for the S/O mark critical points that produce an increase of the reaction kinetic and, consequently, of the formation of expansive products due to the release of sulfates in the cement paste.

Figure 9 presents the microanalysis results of the 16 samples taking either the iron or the oxygen as reference for the atomic ratios. Again, critical values of $\mathrm{Fe} / \mathrm{O}$ and $\mathrm{O} / \mathrm{S}$ lead to the activation and acceleration of the oxidation of pyrrhotite in the samples analyzed. This seems evident in Figure $9 \mathrm{~b}$ that relates the $\mathrm{Fe} / \mathrm{O}$ and $\mathrm{O} / \mathrm{S}$ atomic ratio in logarithmic scale. It shows that for $\mathrm{Fe} / \mathrm{O}$ less than 2.44 and $\mathrm{S} / \mathrm{O}$ less than 2.63 , the analyzed points are close to the representative atomic ratios of the iron oxides $\left(\mathrm{Fe}_{2} \mathrm{O}_{3}\right)$ and hydroxides $\left(\mathrm{FeO}(\mathrm{OH}), \mathrm{Fe}(\mathrm{OH})_{3}\right)$.

However, for values of $\mathrm{Fe} / \mathrm{O}$ and $\mathrm{O} / \mathrm{S}$ higher than the limits defined, the points start the oxidation process (in green) following a decreasing linear tendency characteristic of the conversion of a pyrrhotite structure into a pyrite stoichiometry. A new representation for the pyrrhotite oxidation process is proposed in Figure 10 based on the experimental results described previously.

According to this new process, the oxidation of pyrrhotite goes through three distinct stages. First, the pyrrhotite is in the non-oxidized form, representing a very low or no presence of oxygen (Stage I). Then, oxidation starts and restructuring of the
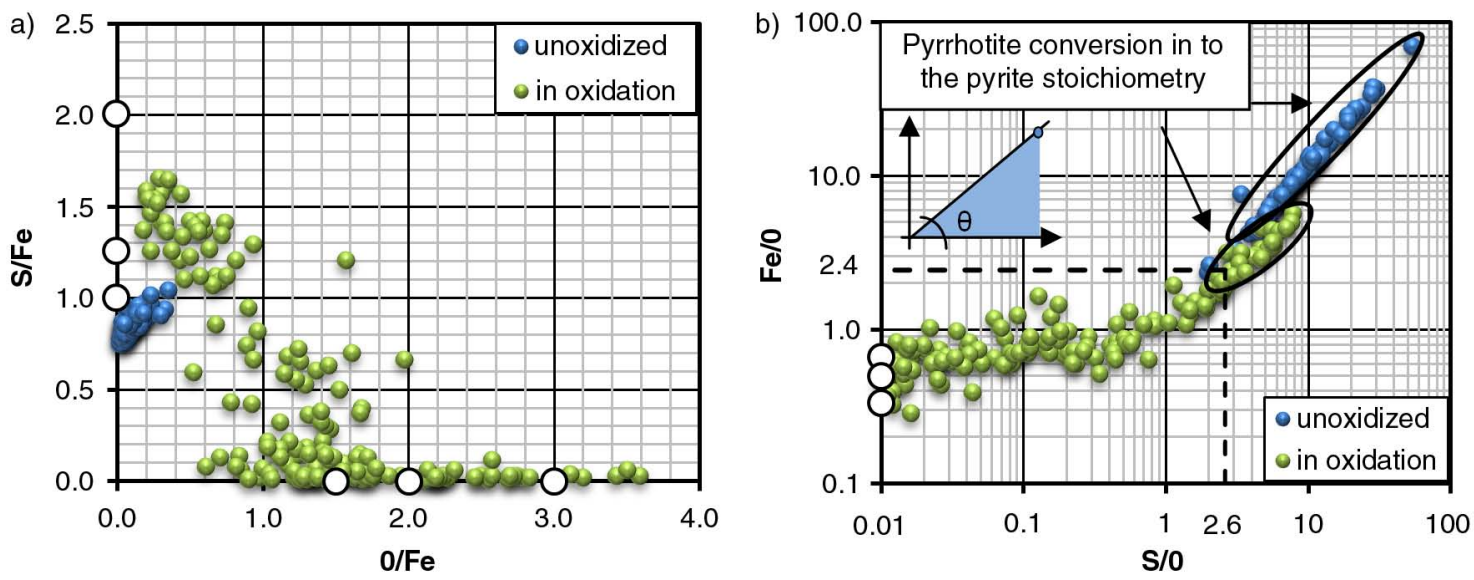

FIGURE 9. Pyrrhotite oxidation process. 


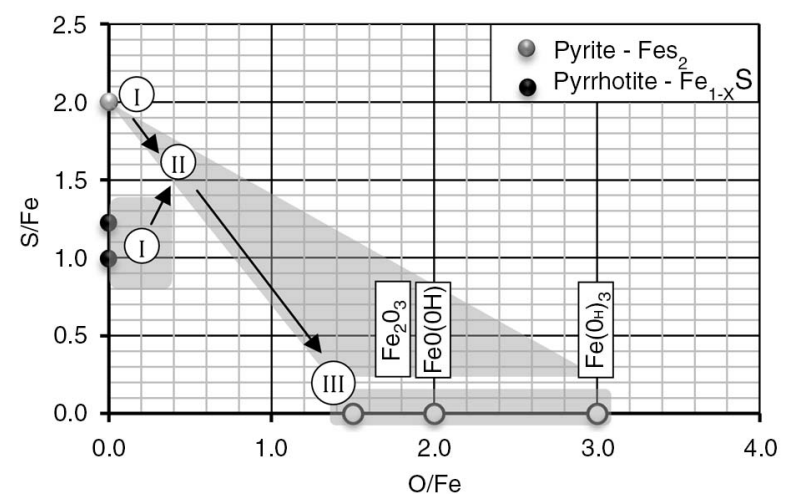

FIGURE 10. New representation for the pyrrhotite oxidation.

pyrrhotite into pyrite occurs due to the diffusion of iron through the pyrrhotite surface (Stage II). Finally, the products of the pyrrhotite oxidation are formed (Stage III).

Notice that the new representation also includes the conversion path for the pyrite. In this case, the conversion path starts for the non-oxidized particle at a $\mathrm{S} / \mathrm{Fe}$ ratio of 2 . Then, as pyrite becomes in contact of oxygen, the reaction gradually goes through stages II and III.

\section{CONCLUSIONS}

The predominant iron sulfide present in the analyzed host rock samples is the pyrrhotite, which generally appears in the host rock as bands with a plate-shaped geometry. These bands mark planes of weakness, which are susceptible to the appearance of cracks. It was also found that characteristic ratios of 2.44 for the $\mathrm{Fe} / \mathrm{O}$ ratio and of 2.63 for the $\mathrm{S} / \mathrm{O}$ ratio mark critical limits that produce the activation and acceleration of the pyrrhotite oxidation. This should lead to an increase of the expansive reactions and, consequently, of the risk of structural damage.

It was confirmed that the cracks mark a preferential path for the entry of the oxidizing agent (oxygen). Thus, the analyzed aggregates that present pyrrhotite bands with cracks show a degree of oxidation much more pronounced than the aggregates without cracks. Such consideration is of the outmost importance for the development of models to predict the evolution of the expansive reactions since it indicates that the diffusion of oxygen should be considered through the cracks rather than through the aggregate.

The microanalysis and the chemical study validate the new representation proposed for the progress of the pyrrhotite oxidation. According to this new representation, initial restructuring of the pyrrhotite into pyrite stoichiometry occurs due to the iron diffusion to the surface of the particle. After this, the surface oxidize, resulting in oxides and finally in iron hydroxides. This new representation should also be considered when modelling the kinetics of the reactions that govern the expansive mechanism and the resulting damage.

\section{ACKNOWLEDGEMENTS}

Funding and support of this research was provided by the Research Contract UPC - ENDESA (Dam Project) and IBERDROLA (Horex Project). The authors would like to thank the technical support of: Juan Manuel Buil and Felipe Rios by ENDESA and Arturo Gil and Ana Belen Martin Vacas by IBERDROLA. This study has been conducted in collaboration with the Department of Building Materials of the Ecole Polytechnique Federale de Lausanne - EPFL (Switzerland).

\section{REFERENCES}

1. Cárdenes, V.; García-Guinea, J.; Monterroso, C.; de la Horra, R. (2008) Protocol for assessing the effectiveness of protective coatings for roofing slate. Mater. Construc., 58 [289-290], 263-279. http://dx.doi.org/10.3989/mc.2008. v58.i289-290.68.

2. Aguado, A.; Agulló, L.; Casanova, I.; López, C.M. (1998) Estudio de fenómenos expansivos en presas de hormigón. De la micro a la macro estructura. Comité Español de Grandes Presas. Premio José Torán.

3. Casanova, I.; Agulló, L.; Aguado, A. (1996) Aggregate expansivity due to sulfide oxidation - I. Reaction system and rate model. Cem. Concr. Res., 26, 993-998. http:// dx.doi.org/10.1016/0008-8846(96)00085-3.

4. Czerewko, M.A.; Cripps, J.C.; Reid, J.M.; Duffell, C.G. (2003) Sulfur species in geological minerals - sources and quantification. Cem. Concr. Res., 25, 657-671. http:// dx.doi.org/10.1016/S0958-9465(02)00066-5.

5. Gomides, J.M.J. (2009) Investigação de agregados contendo sulfetos e seus efeitos sobre a durabilidade do concreto. $\mathrm{PhD}$ Tesis (in portuguese), Porto Alegre.

6. Lee, H.; Cody, R.D.; Cody, A.M.; Spry, P.G. (2005) The formation and role of ettringite in Iowa highway concrete deterioration. Cem. Concr. Res., 35, 332-343. http://dx.doi. org/10.1016/j.cemconres.2004.05.029.

7. Oliveira, I.; Cavalaro, S.H.P.; Aguado, A. (2013) New Unreacted-Core Model to Predict Pyrrhotite Oxidation in Concrete Dams. J. Mater. Civ. Eng., 25 [3], 372-381. http:// dx.doi.org/10.1061/(ASCE)MT.1943-5533.0000531.

8. Oliveira, I.; Cavalaro, S.H.P.; Aguado, A. (2013) New kinetic model to quantify the internal sulfate attack in concrete. Cem. Concr. Res., 43, 95-104. http://dx.doi.org/10.1016/j. cemconres.2012.09.010.

9. Becker, M. (2004) The mineralogy and crystallography of pyrrhotite from selected nickel and PGE ore deposits and its effects on flotation performance. PhD Tesis, University of Pretoria.

10. Chinchon, J.S.; Ayora, C.; Aguado, A.; Guirado, F. (1995) Influence of weathering of iron sulfides contained in aggregates on concrete durability. Cem. Concr. Res., 25, 1264 1272. http://dx.doi.org/10.1016/0008-8846(95)00119-W.

11. Janzen, M.P.; Nicholson, R.V.; Scharer, J.N. (2000) Pyrrhotite reactions kinetics: reaction rates for oxidation by oxygen, ferric iron, and for nonoxidative dissolution. Geochimica et Cosmochimica Acta, 64, 1511-1522. http://dx.doi.org/ 10.1016/S0016-7037(99)00421-4.

12. Steger, H.F. (1982) Oxidation of sulfide minerals VII. Effect of temperature and relative humidity on the oxidation of the pyrrhotite. Chem. Geol., 35, 281-295. http:// dx.doi.org/10.1016/0009-2541(82)90006-7. 
13. Tagnit-Hamou, A.; Saric-Coric, M.; Rivard, P. (2005) Internal deterioration of concrete by the oxidation of pyrrhotitic aggregates. Cem. Concr. Res., 35, 99-107. http:// dx.doi.org/10.1016/j.cemconres.2004.06.030.

14. Schmidt, T.; Leemann, A.; Gallucci, E.; Scrivener, K.L. (2009) Microstructural investigations of iron sulfide degradation in concrete. Int. Baustofftagung (IBAUSIL), Weimar, Germany, 23-26.

15. García-Guinea, J; Cardenes, V: Lombardero, $\mathrm{M}$; Desiloniz, M.I. (2002) Determination of iron sulphides in roofing slates from the north west of Spain. Mater. Construc., 52 [266], 55-63. http://dx.doi.org/10.3989/mc. 2002.v52.i266.334.

16. Ayora, C.; Chinchón, S.; Aguado, A.; Guirado, F. (1998) Weathering of iron sulfides and concrete alteration: thermodynamic model and observation in dams from Central Pyreness, Spain. Cem. Concr. Res., 28, 1223-1235. http:// dx.doi.org/10.1016/S0008-8846(98)00137-9.

17. Mycroft, J.R.; Nesbitt, H.W.; Pratt, A.R. (1995) X-ray photoelectron and Auger electron spectroscopy of air-oxidized pyrrhotite: Distribution of oxidized species with depth. Geochimica et Cosmochimica Acta., 59, 721-733. http:// dx.doi.org/10.1016/0016-7037(94)00352-M

18. Pratt, A.R.; Muir, I.J.; Nesbitt, H.W. (1994) X-ray photoelectron and Auger electron spectroscopic studies of pyrrhotite and mechanism of air oxidation. Geochimica et Cosmochimica Acta., 58, 827-841. http://dx.doi.org/ 10.1016/0016-7037(94)90508-8.
19. Jones, C.F.; Lecount, S.; Smart, R.; White, T. (1992) Compositional and structural alteration of pyrrhotite surfaces in solution: XPS and XRD studies. Appl. Surf. Sci., 55, 65-85. http://dx.doi.org/10.1016/0169-4332(92)90382-8.

20. Belzile, N.; Chen, Y.; Cai, M.; Li, Y. (2004) A review on pyrrhotite oxidation. J. Geochem. Exploration., 84, 65-76. http://dx.doi.org/10.1016/j.gexplo.2004.03.003.

21. Legrand, D.L.; Bancroft, G.M.; Nesbitt, H.W. (2005) Oxidation/alteration of pentlandite and pyrrhotite surfaces at $\mathrm{pH}$ 9.3: Part I - assignment of XPS spectra and chemical trends. Am. Mineral., 90, 1042-1054. http://dx.doi. org/10.2138/am.2005.1691

22. Oliveira, I.; Chinchón-Paya, S.; Aguado, A.; Chinchón, S. (2011) Pyrrhotite oxidation kinetics: host rock influence and the effect of aggregate size on a concrete dam. XIII ICCC - International Congress on Chemistry of Cement, Madrid, Spain, ISBN: 84-7292-399-7.

23. Araújo, G.S. (2008) La reacción sulfática de origen interno en presas de hormigón. Propuesta metodológica de análisis. PhD Tesis (in spanish). Universidad Politécnica de Catalunya, Barcelona.

24. Oliveira, I. (2011) Reacción sulfática interna en presas de hormigón: cinética del comportamiento. PhD Thesis. Polytechnic University of Catalunya (in Spanish), Barcelona.

25. Divet, L. (2001) Les reactions sulfatiques internes au beton. Contribution à l'etude des mecanismes de la formation differee de 1'ettringite. PhD Thesis, Conservatoire National des Arts et Metiers, Paris. 